\title{
Öğretmenlerin Gömlek Satın Alma Davranışları ve Gömleklere Yönelik Geri Dönüşüm Konusundaki Görüşleri: Konya Örneği*
}

\section{Teachers' Shirt Buying Behaviors and Views on Recycling Shirts: The Case of Konya}

\author{
Öğr. Gör. Kartal Murat AYVAZ ${ }^{\text {ID) }}$, Doç. Dr. Hatice HARMANKAYA (D)2
}

\begin{abstract}
$\ddot{O} \mathbf{z}$
Bu araştırmanın amacı: "Konya da bulunan milli eğitim bakanlığına bağlı okullarda görev yapan öğretmenlerin gömlek satın alma davranışlarını ve gömleklere yönelik geri dönüşüm konusundaki görüşlerini saptamak" olarak belirlenmiştir. Betimsel araştırma yönteminin kullanıldığ çalışmanın evrenini Konya ili merkez ilçelerde MEB'e bağlı okullarda görev yapan öğretmenler; örneklemini ise bu okullarda görev yapan ve seçkisiz olarak belirlenen 373 öğretmen oluşturmaktadır. Araştırma ile ilgili olarak, katılımcılardan verileri elde etmeye yönelik anket formu geliştirilmiş ve uygulanmıştır. Anket üç ana bölümden ve toplam 116 sorudan oluşmaktadır. Anketler üzerinde istatistiksel analizler yapılmak üzere veriler SPSS paket programına aktarılmıştır. SPSS programına aktarılan verilerin frekans, yüzdelik dağılımlar, aritmetik ortalama, çapraz tablo analizi, t-testi, anova, korelasyon ve faktör analizlerinden yararlanılmıştır. Ayrıca bulgular cinsiyet değişkeni dikkate alınarak çapraz tablolarda verilmiştir. Likert sorulardan elde edilen verilerin toplamları alınarak ortalamaları elde edilmiştir. Değişkenler arasındaki istatistiksel ilişkinin anlamlı olup olmadığını tespit etmek için T testi yapılmışıır. T testinin sonuçları ilgili kısımlarda kullanılmıştır. Araştırmaya göre; katılımcıların geri dönüşüm konusuna olumlu yaklaştıkları görülmüş̧ür. Katılımcıların, geri dönüşüm ve yeniden kullanım konusunu önemli görmelerine rağmen zamanlarının kısıtlı olması, dikiş bilgilerinin olmaması ve hazır giyim ürünlerinin ucuz olması gibi sebeplerle geri dönüşüm için gerekli faaliyetleri kendilerinin yapmak istemedikleri/ yapamadıklar1/ yapmadıkları ancak geri dönüşümü sağlanmış bir ürünü satın alıp kullanabilecekleri sonuçlarına ulaşılmıştır.
\end{abstract}

Anahtar Kelimeler: Ekoloji, giyim, geri dönüşüm, sürdürülebilirlik, tekstil ve moda

Makale Türü: Araştırma

\begin{abstract}
The purpose of this study was determined as "to determine the shirt buying behavior of teachers working in schools affiliated to the Ministry of National Education in Konya and their opinions on the recycling of shirts". Teachers working in schools affiliated to the Ministry of National Education in central districts of Konya province; The sample consists of 373 teachers working in these schools and determined randomly. A questionnaire form was developed and applied to obtain data from the participants regarding the research. The questionnaire consists of three main parts and a total of 116 questions. The data were transferred to the SPSS package program for statistical analysis on the questionnaires. Frequency, percentage distributions, arithmetic mean, cross-table analysis, t-test, anova, correlation and factor analysis of the data transferred to the SPSS program were used. In addition, the findings are given in cross tables considering the gender variable. The averages of the data obtained from Likert questions were obtained by taking the sum of the data. T test was conducted to determine whether the statistical relationship between variables was significant or not. The results of the $\mathrm{T}$ test are used in the relevant sections. According to the research; It has been observed that the participants have a positive approach to

\footnotetext{
*Bu makale, 30.05.2018 tarihinde Selçuk Üniversitesi Sosyal Bilimler Enstitüsünde Doç. Dr. Hatice Harmankaya'nın danışmanlığında kabul edilen “Öğretmenlerin Gömlek Satın Alma Davranışları ve Gömleklere Yönelik Geri Dönüşüm Konusundaki Görüşleri: Konya Örneği”’ başlıklı yüksek lisans tezinin bir özetidir.

${ }^{1}$ Avrasya Üniversitesi, Meslek Yüksekokulu, kmurat.ayvaz@avrasya.edu.tr

${ }^{2}$ Selçuk Üniversitesi, Mimarlık ve Tasarım Fakültesi, harmankayahatice@ selcuk.edu.tr
}

Atıf için (to cite): Ayvaz, K. M., \& Harmankaya, H. (2021). Öğretmenlerin gömlek satın alma davranışları ve gömleklere yönelik geri dönüşüm konusundaki görüşleri: Konya örneği. Afyon Kocatepe Üniversitesi Sosyal Bilimler Dergisi, 23(4),1555-1566. 
recycling. Although the participants consider recycling and reuse important, they have reached the conclusion that they do not want to do / cannot do / do the necessary activities for recycling themselves, but they can buy and use a recycled product due to their limited time, lack of sewing knowledge and cheap ready-to-wear products.

Keywords: Ecology, clothing, recycling, sustainability, textile and fashion.

Paper type: Research

\section{Giriş}

İnsanoğlunun en önemli ihtiyaçlarından biri olarak görülen giyim; geçmişin farklı yaşam şekillerini yansıtan, siyasi, ekonomik ve sosyo- kültürel şartlara göre şekillenen, dönemin sanatsal yönlerini betimleyen bir araçtır (Şahin, 2009, s. 2-3). Tarihi seyir içerisinde; felsefi, düşünsel, ekonomik, iktisadi, siyasi ve kültürel sistemler değişmiş ve bu değişimler giyim ve giysi kavramlarına, olgularına, uygulamalarına da yeni yaklaşımlar getirmiștir. Özüdoğru'ya göre: Özellikle Fransız devrimiyle sınıflar arası sınırların kalkması, C. F. Worth'ün kendi moda evini kurması, moda ve kadın dergilerinin yayımlanmaya başlaması, endüstri devrimi, kapitalist ekonomik sistem, seri üretim ve küreselleşmeyle birlikte kurumsallaşmış modern bir moda sistemi ortaya çıkmıştır (Özüdoğru, 2013, s. 213). Modernite anlayışı çerçevesinde şekillenen tekstil, hazır giyim, moda sektörü özellikle medya aracılı̆̆ıyla, giysiye; dış etkilerden korumak, mahrem yerleri örtmek ve süslenmek gibi temel görevlere ek olarak sosyolojik, psikolojik, siyasal, kültürel, ideolojik ve iletişimsel bazı misyonlar da kazandırmıştır. Giyim ve moda artık paradigmalardan oluşan bir göstergeler dünyası elemanı ve iletişim aracıdır. İnsan hayatının en temel eşyası ve çok yönlü sofistike bir aracı olan giysi ve giyim anlayışı, mevcut ekonomik sistemdeki hızlı üretim- tüketim anlayışı vasıtasıyla geri döndürülmesi mümkün olmayan atıklar oluşturmaya başlamıştır. İnsanlık tarihinin dönüm noktalarından kabul edilebilecek aydınlanma çağı ve endüstri devrimi; süreçleri ve sonuçları itibariyle, insanın dünyayı algılayış ve kavrayıșını kökten değiștirmiștir. Özellikle 19. Yüzyıldan itibaren dünyayı etkisi altına alan kapitalist ekonomi, endüstrileşme, küreselleşme, hızlı nüfus artışı, kentleşme ve hızlı üretim/ tüketim anlayışı ve uygulamaları sonucunda ciddi çevre sorunları ortaya çıkmaya başlamıştır. Yeni dünya düzeni; ekosistemin zarar görmesi, atıkların artması, doğal kaynakların tükenmesi, canlı türlerinin yok olması, ozon tabakasının incelmesi ve iklim değişikliği gibi birçok tehdidi beraberinde getirmiştir. Bu duruma karşıt bir felsefi anlayışla hareket eden sürdürülebilirlik temelli ekoloji ve geri dönüşüm uygulamaları tüm sektörlerde olduğu gibi tekstil ve hazır giyim sektöründe de giderek yaygınlaşmaktadır.

Son dönemlerde tekstil ve hazır giyim sektöründe çevresel sürdürülebilirlik konuları önem kazanmaktadır. Birincil uygulamalar, zararlı kimyasalların çevre dostu maddelerle değiştirilmesi ve giyim eşyalarının geri dönüş̧ürülmesiyle atık ve kaynak tüketiminin azaltılmasını içermektedir (Jung \& Jin, 2014, 510). Sürdürülebilirlik, insan geçim ve refahını etkileyen hem küresel hem de yerel olarak ekolojik, ekonomik ve sosyopolitik boyutları kesişen, karmaşık çevresel dinamikleri içermektedir (Joy et al. 2012, s. 274). Sürdürülebilirlik, geri dönüştürülmüş materyallerin ve biyolojik olarak parçalanabilir liflerin kullanımını teşvik eder (Shen et al. 2013, s. 135).

Tekstil ve hazır giyim sektöründe mevcut sistem; sürekli üretimi, yeni müşteri ihtiyaçlarını ve yeni ürünleri amaçlayan moda akımlarının hızlı döngüsüne dayanır. Ürünlerin ömürleri kısalmakta ve şirketler ürünlerinin daha yüksek bir hızda değiştirilmesini istemektedirler (Niinimäki \& Hassi, 2011, s. 1878). Dünyada her yıl yaklaşık 80 - 100 milyar ton hazır giyim ürünü üretildiği tahmin edilmektedir. Amerika Birleşik Devletleri'nde son 20 yılda her yıl son kullanıcıdan kaynaklı 15 milyon ton tekstil atığı meydana gelmiştir. 1 ton tekstil üretmek için yaklaşık 200 ton su harcanır ve sektörde yaklaşık 8.000 farklı kimyasal kullanılmaktadır (Batelier, 2018). Boston Consulting Group Moda Endüstrisinin Nabzı raporuna göre; 2030 y1lında dünya nüfusunun 8,5 milyar olacağ1 öngörüsünden hareketle bugün 62 milyon olan hazır giyim tüketimi, \%63 artarak 102 milyona ulaşmış olacaktır (Global Fashion 
Agande, 201, s. 8). Tekstil ve hazır giyim sektöründe her yıl 80-100 milyon ton civarında üretim gerçekleştiriliyor. Bu ürünlerin \%76'sı atık haline geliyor. 2050 yılında 10 milyara çıkması beklenen nüfusun da etkisiyle hammadde ve kaynak yetersizliğinin yanında atık sorunu da sürdürülemez duruma gelecektir (İTKİB, 2021, s. 69- 70). Tekstil ve hazır giyim sektöründe oluşan atıklar genel olarak; tüketici öncesi atıklar (üretim esnasında oluşan) ve tüketici atıkları (tüketim sonrası oluşan) şeklinde gruplandırılabilir.

İşlevini tamamlayan her malzeme atık olarak kabul edilir. Atık ekolojisi kavramı ise kullanımı sona eren tekstil ürünlerinin zararlı maddeler yaymaksızın yok edilmesi esaslarına dayandırılmıştır. $\mathrm{Bu}$ alanda en önemli çözüm recyling'dir. Yani eskiyen tekstil ürünlerinin liflerinin kullanılmasıdır (İTKİB, 2005, s. 4). Atıkların değerlendirme yolları gömme, yakma, gazlaştırma ve piroliz yöntemleridir. Geri dönüşüm için ise en önemli değerlendirme metodu piroliz yöntemidir (Üçgül ve Elibüyük, 2014, s. 40- 46). Bunun dışında atıkların dişlilerle parçalanıp, taranıp elyaf haline getirilmesi işlemi de geri dönüşüm açısından oldukça kazançlı bir yöntemdir. Bunun dışında, tekstil atıkları hurdacılar tarafından toplanarak şekil ve tiplerine göre sınıflandırılıp tiftikleme makinesine atılmakta ve bazı tekstil atıklarından keçe ve temizlik aracı yapılmaktadır.

Kullanılmış hazır giyim atıkları ise; tekstil atık kutuları vb. yöntemlerle toplanmakta ve öncelikle sinıflandırılmakta, kullanılabilecek durumda olanlar ayrilarak ikinci el giysi olarak değerlendirilmekte, kullanılamayacak durumda olanlar da geri kazanım yöntemleriyle değerlendirilmektedir. Ülkemizde son yıllarda sayıları gün geçtikçe artan giysi toplama merkezleri yeniden kullanım açısından oldukça önemlidir. Buralarda toplanan giysiler temizleme işlemleri sonrasında ihtiyaç sahiplerine dağıtılmaktadır. Ülkemizde nadir olarak bazı büyük şehirlerde gönüllü kişiler tarafından gerçekleştirilen takas usulü ile giysilerin değerlendirilmesi yöntemi de yine büyük kazançlar sağlamaktadır.

\section{Yöntem}

Öğretmenlerin gömlek satın alma davranışları ve gömleklerin geri dönüşümüne yönelik görüşlerini belirleyebilmek amacıyla yapılmış olan bu çalışmada betimsel araştırma yöntemi kullanılmıştır. Betimsel yöntem, araştırılmak istenen problemin var olan mevcut durumunu ortaya koymaya yöneliktir. Mevcut durumu kendi koşulları içerisinde ve olduğu gibi çalışmak betimsel yöntemlerin en temel özelliği olarak kabul edilir (Sönmez ve Alacapınar, 2011, s. 11).

Araştırmanın evreni, Konya ili merkez ilçelerde (Selçuklu, Karatay, Meram) MEB'e bağlı okullarda görev yapan öğretmenlerden oluşmaktadır. Araştırmanın örneklemi ise, MEB'e bağl1 bu okullarda görev yapan ve basit seçkisiz örnekleme yöntemi ile belirlenen 373 gönüllü öğretmenden oluşmaktadır. Örneklem sayısı, aşağıda belirtilen veriler kullanılarak formül ile hesaplanmıştır.

Kurum: Konya İl Milli Eğitim Müdürlüğüne Bağlı Okullar

Evren: 13.359

$\mathrm{N}=$ Evrendeki Birey Sayıs

$\mathrm{Z}=$ Güvenilirlik Katsayısı (\%95 için): 1.96

$\mathrm{D}=$ Standart Hata: 0.05

Değişkenin Varyans1: 0,5

N.Z $Z^{2} \cdot(0.5)^{2}$

$(\mathrm{N}-1) \cdot \mathrm{D}^{2}+\mathrm{Z}^{2} \cdot(0.5)^{2}$

$$
\begin{aligned}
& 13.359 \times(1.96)^{2} \times(0.5)^{2} \\
& (13359-1) \times(0.05)^{2}+(1.96)^{2} \times(0,5)^{2}
\end{aligned}
$$


$\mathrm{n}=373$

Örneklem: 373

Verilerin formüle uygulanması sonucunda araştırmada olması gereken örneklem büyüklüğ̈̈ 373 kişi olarak belirlenmiştir. Araştırma ile ilgili olarak katılımcılardan verileri elde etmeye yönelik istenilen güven aralığında anket formu geliştirilmiş ve uygulanmıştır. Araştırma da katılımcıların gömlek satın alma davranışları, atık ekolojisi ve gömleklerin geri dönümüne yönelik yaklaşım ve görüşleri ölçülmüş̧ür. Araştırmanın kuramsal temelini oluşturmak ve ankette yer alacak soruları belirlemek amacıyla alanla ilgili literatür taraması yapılmıştır. Anket üç ana bölümde toplam 116 sorudan oluşmaktadır. Anket formunun başlangıcında araştırmanın amacı ve anketin ne şekilde cevaplandırılacağı açıklanmıştır. Birinci bölümde katılımcıların demografik özelliklerini belirlemek amacıyla iki soru bulunmaktadır. Bu sorular kapalı uçlu çoktan seçmeli olarak hazırlanmıştır. İkinci bölümde, gömlek satın alma davranışları ve bu konulardaki düşüncelerini öğrenmek amacıyla on soruya yer verilmiştir. Soruların yedisi kapalı uçlu çoktan seçmeli, üçü “Önemsiz- 2- 3- 4- Çok önemli” şeklinde derecelendirilmiş 5'li likert olarak verilmiştir. Üçüncü ve son bölümde ise; katılımcıların atık ekolojisi ve gömleklerin geri dönüşümüne yönelik bilgi ve düşüncelerinin ölçülmesi amacıyla üç soruya yer verilmiştir. Sorulardan biri kapalı uçlu çoktan seçmeli, ikisi ise "Kesinlikle katılmıyorum- 2- 3- 4Kesinlikle katılıyorum" şeklinde derecelendirilmiş 5'li likert sorulardır. Anket formu oluşturulduktan sonra elli kişiye pilot uygulama yapılmıştır. Bu pilot uygulamalar esnasında anlaşılmayan sorular ve maddeler yeniden düzenlenmiştir. Uygulanan anketler kontrol edilip eksik ya da hatalı olanları ayrılmış ve doğru olan anketler üzerinde istatistiksel analizler yapılmak üzere veriler SPSS paket programına aktarılmıştır. SPSS programına aktarılan verilerin frekans, yüzdelik dağılımlar, aritmetik ortalama, t-testi ve çapraz tablo analizlerinden yararlanılmıştır. Bu testlerin gerekli görülenleri ilgili kısımlarda verilmiştir. Tablolarda sayı ve $\%$ şeklinde gösterilen bulgular yorumlanmıştır. Ayrıca bulgular cinsiyet değişkeni dikkate alınarak çapraz tablolarda verilmiştir. Likert sorulardan elde edilen verilerin toplamları alınarak ortalamaları elde edilmiş̧tir. Değişkenler arasındaki istatistiksel ilişkinin anlamlı olup olmadığını tespit etmek için $\mathrm{T}$ testi yapılmıştır. $\mathrm{T}$ testinin sonuçları ilgili kısımlarda kullanılmıştır. İlişki testi için hipotezler aşağıdaki şekilde yapılandırılmıştır:

HO: Örneklemde cinsiyet veya yaş faktörleri ile gömlek satın alma davranışları ve gömleklerin geri dönüşümüne yönelik görüşlerine ilişkin değişkenler arasında istatistiksel bir ilişki yoktur.

H1: Örneklemin cinsiyet veya yaş faktörleri ile gömlek satın alma davranışları ve gömleklerin geri dönüşümüne yönelik görüşlerine ilişkin değişkenler arasında istatistiksel bir ilişki vardır. Hipotezlerin kabul ya da reddi için olasılık değeri $(\mathrm{p})<=0.05$ ise H1 kabul edilir.

\section{Bulgular}

Araştırmaya katılan öğretmenlerin \%65,8'i (231) erkek ve \%34,2'si (120) kadındır. Yaş grubu dağılımları incelendiğinde ise 41-50 yaş grubunda \%43,3 (152), 31-40 yaş grubunda $\% 29,1$ (102), 51-60 yaş grubunda \%14 (49), 25-30 yaş grubunda \%9,7 (34), 61 ve üzeri yaş grubunda \%4 (14) katılımcı bulunduğu görülmüştür. Yaş grubu dağılımları arasında en çok katılımc1 41-50 yaş grubundadır. En az katılımcı ise 61 ve üzeri yaş grubundadır.

Öğretmenlerin gömlek alışverişi yapma sıklıkları incelendiğinde; \%47'sinin altı ayda bir, \%24,8'inin üç ayda bir gömlek alışverişi yaptığı belirlenmiştir.

Hem kadınlar $(\% 50)$ hem de erkekler $(\% 45,5)$ tarafindan en çok tercih edilen alışveriş sıklığı "altı ayda bir" seçeneğidir. Kadınlar $(\% 1,7)$ ve erkekler $(\% 5,6)$ tarafından en az tercih edilen gömlek satın alma sıklığı ise "ayda bir" seçeneğidir. Öğretmenlerin yaklaşı \%50'sinin genel olarak "altı ayda bir" gömlek Alışverişi yaptığı ortaya çıkmıştır. Katılımcıların \%16' sının ise gömlek alışverişlerini yaparken düzenli herhangi bir sıklık takip etmedikleri belirlenmiştir. Aktuğlu ve Temel'in "kamu sektörü çalışanlarının giysi markalarını tercihini etkileyen 
faktörlere yönelik bir araştırma" adlı çalışmalarında tüketicilerin \%42,2'si "altı ayda bir kez" ve \%8,6's1 "yılda bir kez" giyim ihtiyacını karşılamak için alışverişe çıktıkları sonucuna ulaşılmıştır (Aktuğlu ve Temel, 2006, s. 43- 59). Gömlek, kamu sektöründe çalışan özellikle öğretmenler için en çok kullanılan giysi türlerindendir. Herhangi bir cinsiyetin daha fazla kullandığ 1 bir giysi türüne sabitlenmeden yapılmış olan giysi satın alma alışkanlıklarını ölçen araştırmalarda, kadın tüketicilerin giysi alışverişi yapma sıklıklarının daha dar aralıklı zamanlarda olduğu görülmektedir. Örnek olarak Budak (2012) tarafından yapılmış olan araştırmada da kadın ve erkek katılımcılar içerisinde genel giyim alışverişi yapma sıklıklarına bakıldığında kadın tüketicilerin daha sık giysi alışverişi yaptıkları belirlenmiştir (Budak, 2012, s. 115). Ancak mevcut çalışmada satın alma sıklığı ölçülen gömleğin, erkek tüketiciler tarafından daha fazla kullanılan bir giysi türü olması sebebiyle araştırma sonuçlarında erkeklerin daha sık gömlek satın aldıkları görülmüştür.

Öğretmenlerin; gömlek alışverişi için harcadıkları aylık miktarlar incelendiğinde; \%51'inin (179) 101-200 TL, \%44,7' sinin (157) 0-100 TL, \%4,3'ünün (15) ise 201-300 TL harcama yaptıkları belirlenmiştir. En çok tercih edilen seçenek 101-200 TL olmuştur.

Tablo 1. Öğretmenlerin kullandıkları gömlek tarzlarının cinsiyet değişkenine göre dağılımı

\begin{tabular}{|c|c|c|c|c|}
\hline \multirow[b]{2}{*}{ SEÇENEKLER } & \multicolumn{2}{|c|}{ Kadın } & \multicolumn{2}{|c|}{ Erkek } \\
\hline & $\mathrm{s}$ & $\%$ & $\mathrm{~s}$ & $\%$ \\
\hline Klasik Gömlekler & 83 & 69.2 & 154 & 66.7 \\
\hline Spor Gömlekler & 71 & 59.2 & 142 & 61.5 \\
\hline Etnik Gömlekler & 5 & 4.2 & 9 & 3.9 \\
\hline Vintage ve Retro Gömlekler & 7 & 5.8 & 9 & 3.9 \\
\hline Sıra Dışı Gömlekler & 13 & 10.8 & 7 & 3 \\
\hline İçinde Rahat Hissedilen Gömlekler & 16 & 13.3 & 1 & 0.4 \\
\hline
\end{tabular}

Tablo 1'de öğretmenlerin kullandıkları gömlek tarzlarının cinsiyet değişkenine göre dağılımı verilmiştir. Gömlek tarzlarında kadınların en çok \%69,2 (83) ile klasik ve \%59,2 (71) ile spor; erkeklerin ise en çok \%66,7 (154) ile klasik ve \%61,5 (142) ile spor gömlekleri tercih ettikleri ortaya çıkmıştır. Kullandıkları gömlek tarzları incelendiğinde; öğretmenlerin toplamda klasik gömlekleri \%67,5 (237), spor gömlekleri \%60,7 (213), sıra dişı gömlekleri \%5,7 (20), içinde rahat hissedilen gömlekleri \%4,8 (17), vintage ve retro gömlekleri \%4,6 (16), etnik gömlekleri \%4 (14) tercih ettikleri görülmüştür. Koca ve Koç' un çalışan kadınlar üzerine yapmış oldukları araştırmada da benzer şekilde, çalışan kadınların \%63,3'ünün klasik giyimi, \%59,7'sinin çoğunlukla spor giyimi tercih ettikleri görülmüştür (Koca ve Koç, 2008, s. 182). Bu bağlamda, ilgili araştırmalarda incelendiğinde çalışanların genel olarak "klasik ve spor" giyim ürünlerini kullandıkları söylenebilir

Tablo 2. Öğretmenlerin gömlek alışverişlerinde tercih ettikleri faktörler

\begin{tabular}{lcccc}
\hline & \multicolumn{3}{c}{ Kadın } & \multicolumn{3}{c}{ Erkek } \\
\cline { 2 - 5 } SEÇENEKLER & $\mathrm{s}$ & $\%$ & $\mathrm{~s}$ & $\%$ \\
\hline Klasik Gömlekler & 83 & 69.2 & 154 & 66.7 \\
\hline Spor Gömlekler & 71 & 59.2 & 142 & 61.5 \\
\hline Etnik Gömlekler & 5 & 4.2 & 9 & 3.9 \\
\hline Vintage ve Retro Gömlekler & 7 & 5.8 & 9 & 3.9 \\
\hline Sira Diş1 Gömlekler & 13 & 10.8 & 7 & 3 \\
\hline İçinde Rahat Hissedilen Gömlekler & 16 & 13.3 & 1 & 0.4 \\
\hline
\end{tabular}

Tablo 2'de araştırma kapsamındaki öğretmenlerin gömlek alışverişlerinde tercih ettikleri faktörler verilmiştir. Öğretmenlerin modaya uygunluğu \%89,2 (313) önemsiz, desenini \%80,1 (281) "2" derecesinde, fiyatın1 \%81,2 (285) "3" derecesinde, markasın1 \%80,6 (283) "3" derecesinde, rengini \%31,1 (109) " 3 " derecesinde, kumaşını \%80,3 (282) "4" derecesinde, kalitesini \%71,5(251), yaşa uygunluğunu \%63,2 (222), modelini \%63 (221) "4" derecesinde ve yine modelini \%24,5 (86) "çok önemli”, yaşa uygunluğunu \%21,1 (74) "çok önemli" şeklinde tercih ettikleri görülmüştür. Öğretmenler gömlek alışverişinde en çok modeline, yaşa uygunluğuna, kalitesi ve kumaşına dikkat ettiklerini belirtmişlerdir. Modaya uygunluğunu ise 
Ayvaz ve Harmankaya / Öğretmenlerin Gömlek Satın Alma Davranışları ve Gömleklere Yönelik Geri Dönüşüm Konusundaki Görüşleri: Konya Örneği / Teachers' Shirt Buying Behaviors and Views on Recycling Shirts: The Case of Konya

önemsiz bulmuşlardır. Öğretmenlerin gömlek alışverişi yaparken en çok tercih ettikleri özelliklerin modeli ve yaşa uygunluğu olması tasarımcılar açısından önemle üzerinde durulması gereken noktalardandır. Yine azımsanmayacak derecede tercih edilen kumaş ve kalite faktörleri de üretimler esnasında dikkat edilmesi gereken faktörlerdendir. Modaya uygunluk faktörünün önemsiz bulunması, klasik tarz gömleklerde değişkenlerin sınırlı olmasından kaynaklanır. Diğer taraftan "fiyatı, kalitesi, kumaşı ve markası" faktörlerinin de hemen hemen hiçbir katılımeı tarafından önemsiz bulunmamış olmasının da üzerinde durulması gerekir. "Kalite ve kumaş" faktörlerinin hem "4" hem de "çok önemli" derecesinde tercih edilmiş olması ve ters bir okumayla "kalite ve kumaş" faktörlerinin hemen hemen hiçbir katılımcı tarafından "önemsiz" derecesinde tercih edilmemiş olması bu faktörlerin oldukça önemli görülüyor olduğunu göstermektedir. Çağman (2010)'ın çalışan kadınlar üzerine yapmış olduğu çalışmada da giysi satın alan çalışan kadınların \%56,4' ünün modayı takip etmediği görülmektedir (Çağman, 2010, s. 55). Aktuğlu ve Temel' in çalışmalarında tüketicilerin giysi satın alma tercihlerini etkileyen faktörlerden rengi/modeli/stili ve kalitesi her zaman etkili olur sonucuna ulaşılmıştır (Aktuğlu ve Temel, 2006, s. 53). Araştırma sonuçları birbirlerini destekler niteliktedir.

Tablo 3. Öğretmenlerin gömlek modellerinde dikkat ettikleri özellikler

\begin{tabular}{|c|c|c|c|c|c|c|c|c|c|c|}
\hline \multirow{2}{*}{ SEÇENEKLER } & \multicolumn{2}{|c|}{ Önemsiz } & \multicolumn{2}{|c|}{2} & \multicolumn{2}{|c|}{3} & \multicolumn{2}{|c|}{4} & \multicolumn{2}{|c|}{$\begin{array}{l}\text { Çok } \\
\text { Önemli }\end{array}$} \\
\hline & $\mathrm{s}$ & $\%$ & $\mathrm{~s}$ & $\%$ & $\mathrm{~s}$ & $\%$ & $\mathrm{~s}$ & $\%$ & $\mathrm{~s}$ & $\%$ \\
\hline Yaka Modeli & - & - & - & - & 287 & 81.8 & 58 & 16.5 & 6 & 1.7 \\
\hline Manşet Modeli & - & - & 12 & 3.4 & 170 & 48.4 & 68 & 19.4 & 101 & 28.8 \\
\hline Cep Modeli & - & - & - & - & 83 & 23.6 & 245 & 69.8 & 23 & 6.6 \\
\hline Kapanma Modeli & 71 & 20.2 & 109 & 31.1 & 117 & 33.3 & 35 & 10 & 19 & 5.4 \\
\hline Kesiminin Vücuduma Uygunluğu & - & - & - & - & 49 & 14 & 279 & 79.5 & 23 & 6.6 \\
\hline Süsleme Modeli & - & - & 21 & 6 & 269 & 76.6 & 25 & 7.1 & 36 & 10.3 \\
\hline Çizgili veya Kareli Olması & - & - & - & - & 23 & 6.6 & 66 & 18.8 & 262 & 74.6 \\
\hline Desen, Motif, Resim Olmas1 & - & - & 23 & 6.6 & 264 & 75.2 & 31 & 8.8 & 33 & 9.4 \\
\hline Kırışmazlık Özelliği Olması & 10 & 2.8 & 22 & 6.3 & 66 & 18.8 & 105 & 29.9 & 148 & 42.2 \\
\hline Kumaşının Pamuklu Olması & 13 & 3.7 & 24 & 6.8 & 76 & 21.7 & 126 & 35.9 & 112 & 31.9 \\
\hline Kolay Ütülenebilir Olması & - & - & - & - & - & - & 71 & 20.2 & 280 & 79.8 \\
\hline Terletmemesi & 12 & 3.4 & 21 & 6 & 68 & 19.4 & 114 & 32.5 & 136 & 38.7 \\
\hline Arma, Logo veya Markanın Görünmesi & 89 & 25.4 & 95 & 27.1 & 88 & 25.1 & 67 & 19.1 & 12 & 3.4 \\
\hline Bilindik Bir Markaya Ait Olması & 16 & 4.6 & 106 & 30.2 & 125 & 35.6 & 104 & 29.6 & - & - \\
\hline Pahalı Bir Markaya Ait Olması & 24 & 6.8 & 109 & 31.1 & 145 & 41.3 & 73 & 20.8 & - & - \\
\hline Markanın Sezon Ürünü Olması & 8 & 2.3 & 27 & 7.7 & 167 & 47.6 & 139 & 39.6 & 10 & 2.8 \\
\hline $\begin{array}{l}\text { Markanın Sezon Sonu veya Geçmiş Sezon } \\
\text { Ürünü Olması }\end{array}$ & 279 & 79.5 & 31 & 8.8 & 41 & 11.7 & - & - & - & - \\
\hline $\begin{array}{l}\text { Marka Kimliğinin Düşünce Yapıma Uygun } \\
\text { Olması }\end{array}$ & 15 & 4.3 & 36 & 10.3 & 221 & 63 & 70 & 19.9 & 9 & 2.6 \\
\hline
\end{tabular}

Tablo 3'e göre; öğretmenler, markanın sezon sonu veya geçmiş sezon ürünü olması özelliğini \% 79,5 (279) ile "önemsiz" derecesinde; arma, logo veya markasının görünür olmas1 özelliğini \% 25.4 (89) ile "önemsiz" derecesinde; pahalı bir markaya ait olması özelliğini \% 31.1 (109) ile "2" derecesinde; bilindik bir markaya ait olması özelliğini \% 30.2 (106) ile " 2 " derecesinde; arma, logo yada markanın görünür olması özelliğini \% 27.1 (95) ile "2" derecesinde; yaka modeli özelliğini \% 81.8 (287) ile " 3 " derecesinde; süsleme modeli özelliğini \% 76.6 (269) ile "3" derecesinde; desen, motif, resim olması özelliğini \% 75.2 (264) ile "3" derecesinde; marka kimliğinin kendi düşünce yapıma uygun olması özelliğini \% 63 (221) ile "3" derecesinde; manşet modeli özelliğini \% 48.4 (170) ile "3" derecesinde; markanın sezon ürünü olması özelliğini \% 47.6 (167) ile " 3 " derecesinde, pahalı bir markaya ait olması özelliğini \% 41.3 (145) ile "3" derecesinde, patlet (kapama) modeli özelliğini \% 33.3 (117) ile "3" derecesinde; kesiminin vücuduma uygunluğu özelliğini \% 79.5 (279) ile "4" derecesinde; cep modeli özelliğini \% 69.8 (245) ile "4" derecesinde; kolay ütülenebilir olması özelliğini \% 79.8 (280) ile "çok önemli” derecesinde, kırışmazlık özelliği olması özelliğini \% 42.2 (148) ile "çok önemli" derecesinde, terletmemesi özelliğini \% 38.7 (136) ile "çok önemli" derecesinde; kumaşının pamuklu olması özelliğini \% 31.9 (112) ile "çok önemli" derecesinde tercih 
etmişlerdir. Katılımcılar gömlek modellerinde en çok "manşet, çizgili kareli olması, kırışmazlık, kolay ütülenebilir olması, terletmemesi, kumaşın pamuklu olması" özelliklerini tercih etmişlerdir. En az ise "arma, logo veya markasının görünür olması, markanın sezon sonu veya geçmiş sezon ürünü olması, pahalı bir markaya ait olması, bilindik bir markaya ait olması" özelliklerini önemli bulmuşlardır. Öğretmenlerin arma, marka ya da logonun görünmesini istemedikleri ve marka faktörüne pek önem vermedikleri söylenebilir.

Tablo 4. Öğretmenlerin kullanılmış giysileri değerlendiren herhangi bir organizasyon, kurum veya projeden haberdar olma durumlarının cinsiyet değişkenine göre dağılımı

\begin{tabular}{lcccc}
\hline \multirow{2}{*}{ SEÇENEKLER } & \multicolumn{2}{c}{ Kadın } & \multicolumn{2}{c}{ Erkek } \\
\cline { 2 - 5 } & $\mathrm{S}$ & $\%$ & $\mathrm{~s}$ & $\%$ \\
\hline Evet var & 2 & 1.7 & 4 & 1.7 \\
\hline Hayır yok & 18 & 15.0 & 28 & 12.1 \\
\hline Olabilir bilmiyorum & 100 & 83.3 & 199 & 86.1 \\
\hline
\end{tabular}

Araştırma kapsamındaki öğretmenlerin kullanılmış giysileri değerlendiren herhangi bir organizasyon, kurum veya projeden haberdar olma durumları incelendiğinde; "olabilir bilmiyorum" seçeneği \%85,2 (299), "hayır yok" seçeneği \%13,1 (46), "evet var" seçeneği ise $\% 1,7$ (6) şeklindedir. En az tercih edilen seçenek "evet var", en çok tercih edilen seçenek ise "olabilir bilmiyorum" seçeneği olmuştur. Katılımcıların büyük çoğunluğunun kullanılmış giysileri değerlendiren herhangi bir organizasyon, kurum veya projeden haberdar olmadikları görülmektedir.

Tablo 5. Öğretmenlerin geri dönüşüm (yeniden kullanım) konusundaki görüşleri

\begin{tabular}{|c|c|c|c|c|c|c|c|c|c|c|}
\hline \multirow[t]{2}{*}{ SEÇENEKLER } & \multicolumn{2}{|c|}{$\begin{array}{c}\text { Kesinlikle } \\
\text { Katılmıyorum }\end{array}$} & \multicolumn{2}{|c|}{2} & \multicolumn{2}{|c|}{3} & \multicolumn{2}{|c|}{4} & \multicolumn{2}{|c|}{$\begin{array}{c}\text { Kesinlikle } \\
\text { Kat1liyorum }\end{array}$} \\
\hline & $\mathrm{s}$ & $\%$ & $\mathrm{~s}$ & $\%$ & $\bar{S}$ & $\%$ & $\mathrm{~s}$ & $\%$ & $\mathrm{~s}$ & $\%$ \\
\hline $\begin{array}{l}\text { Atık ekolojisi, tekstilde/ konfeksiyonda geri } \\
\text { dönüşüm kavramı hakkında bilgim var. }\end{array}$ & - & - & 10 & 2.8 & 71 & 20.2 & 102 & 29.1 & 168 & 47.9 \\
\hline $\begin{array}{l}\text { Gömleklerin yeniden kullanılabilir hale } \\
\text { getirilmesi aile ve ülke ekonomisine katk1 } \\
\text { sağlar. }\end{array}$ & - & - & 11 & 3.1 & 68 & 19.4 & 92 & 26.2 & 180 & 51.3 \\
\hline $\begin{array}{l}\text { Gömleklerin yeniden kullanılabilir hale } \\
\text { getirilmesi yeni istihdam alanları oluşturur. }\end{array}$ & 13 & 3.7 & 35 & 10 & 92 & 26.2 & 133 & 37.9 & 78 & 22.2 \\
\hline $\begin{array}{l}\text { Kullanılmayan gömleklerin atık hacmi } \\
\text { oldukça büyüktür. }\end{array}$ & 54 & 15.4 & 14 & 4 & 185 & 52.7 & 85 & 24.2 & 13 & 3.7 \\
\hline $\begin{array}{l}\text { Gömleklerin yeniden değerlendirilmesine } \\
\text { yönelik projeler geliştirilmesi önemlidir. }\end{array}$ & 26 & 7.4 & 49 & 14 & 167 & 47.6 & 97 & 27.6 & 12 & 3.4 \\
\hline $\begin{array}{l}\text { Gömleklerde geri dönüşüm çevreye karşı } \\
\text { duyarlılığı artırır. }\end{array}$ & 45 & 12.8 & 14 & 4 & 179 & 51 & 97 & 27.6 & 16 & 4.6 \\
\hline $\begin{array}{l}\text { Gömleklerde geri dönüşüm sürdürülebilir } \\
\text { modanın yaygınlaşmasına katkı sağlar. }\end{array}$ & - & - & 59 & 16.8 & 252 & 71.8 & 26 & 7.4 & 14 & 4 \\
\hline $\begin{array}{l}\text { Kamu ve özel kurumların bu konuda önemli } \\
\text { faaliyetler gerçekleştirdiğini düşünüyorum. }\end{array}$ & 48 & 13.7 & 68 & 19.4 & 159 & 45.3 & 62 & 17.7 & 14 & 4 \\
\hline $\begin{array}{l}\text { Gömlekleri yeniden değerlendirmeyi maddi } \\
\text { durumu düşük olanların yapması gerektiğini } \\
\text { düşünüyorum. }\end{array}$ & 54 & 15.4 & 59 & 16.8 & 180 & 51.3 & 48 & 13.7 & 10 & 2.8 \\
\hline $\begin{array}{l}\text { Hazır giyim ürünleri ucuz olduğu için } \\
\text { gömleklerin yeniden değerlendirilmesine } \\
\text { ihtiyaç olmadığını düşünüyorum. }\end{array}$ & 61 & 17.4 & 15 & 4.3 & 202 & 57.5 & 56 & 16 & 17 & 4.8 \\
\hline $\begin{array}{l}\text { Aynı zamanda sosyal bir sorumluluk olan } \\
\text { geri dönüsš̈m yöntemleri ile kullanılır hale } \\
\text { getirilmiş gömlekleri giyerim. }\end{array}$ & 21 & 6 & 20 & 5.7 & 72 & 20.5 & 162 & 46.2 & 76 & 21.7 \\
\hline $\begin{array}{l}\text { Gömleklerin yeniden değerlendirilmesi için } \\
\text { dikiş ve tasarım bilgisine ihtiyaç vardır. Bu } \\
\text { nedenle herkes yapamaz. }\end{array}$ & 26 & 7.4 & 23 & 6.6 & 78 & 22.2 & 135 & 38.5 & 89 & 25.4 \\
\hline $\begin{array}{l}\text { Zamanım olmadığ için giysilerin yeniden } \\
\text { kullanımına yönelik faaliyetler yapamam. }\end{array}$ & 26 & 7.4 & 23 & 6.6 & 82 & 23.4 & 131 & 37.3 & 89 & 25.4 \\
\hline
\end{tabular}

Tablo 5'e göre; öğretmenlerin \% 71.8 (252)'i “gömleklerde geri dönüşüm sürdürülebilir modanın yaygınlaşmasına katkı sağlar”, \% 57.5 (202)' i "hazır giyim ürünleri ucuz olduğu için gömleklerin yeniden değerlendirilmesine ihtiyaç olmadığını düşünüyorum”, \% 52.7 (185)’ si 
Ayvaz ve Harmankaya / Öğretmenlerin Gömlek Satın Alma Davranışları ve Gömleklere Yönelik Geri Dönüşüm Konusundaki Görüşleri: Konya Örneği / Teachers’ Shirt Buying Behaviors and Views on Recycling Shirts: The Case of Konya

"kullanılmayan gömleklerin atık hacmi oldukça büyüktür”, \% 51.3 (180)' ü "gömlekleri yeniden değerlendirmeyi maddi durumu düşük olanların yapması gerektiğini düşünüyorum”, \% 47.6 (167)'s1 “gömleklerin yeniden değerlendirilmesine yönelik projeler geliştirilmesi önemlidir”, \% 51 (179)' i “gömleklerde geri dönüşüm çevreye karşı duyarlılığı artırır”, \% 45.3 (159)' ü 'kamu ve özel kurumların bu konuda önemli faaliyetler gerçekleştirdiğini düşünüyorum” ifadelerine “ 3 ” derecesinde katılmışlardır. Öğretmenlerin \% 46.2 (162)' si "aynı zamanda sosyal bir sorumluluk olan, geri dönüşüm yöntemleri ile kullanılır hale getirilmiş gömlekleri giyerim", \% 38.5 (135)' i 'gömleklerin yeniden değerlendirilmesi için dikiş ve tasarım bilgisine ihtiyaç vardır bu nedenle herkes yapamaz", \% 37.9 (133)' u "gömleklerin yeniden kullanılabilir hale getirilmesi yeni istihdam alanları oluşturur”, \% 37.3 (131)'ü "zamanım olmadığı için giysilerin yeniden kullanımına yönelik faaliyetler yapamam" ifadelerine "4 derecesinde" katılmışlardır. Öğretmenlerin \%51,3 (180)' ünün "gömleklerin yeniden kullanılabilir hale getirilmesi aile ve ülke ekonomisine katkı sağlar", “\%47,9 (168)' unun "atık ekolojisi, tekstilde/ konfeksiyonda geri dönüşüm kavramı hakkında bilgim var" düşüncelerine kesinlikle katıldıkları belirlenmiştir. Katılımcılar, gömleklerin yeniden kullanılabilir hale getirilmesinin aile ve ülke ekonomisine olumlu katkılar sağlayacağını, yeni istihdam alanları oluşturacağını ve gömleklerin yeniden değerlendirilmesine yönelik projeler geliştirilmesinin önemli olduğunu belirtmişlerdir. Bunların dışında gömleklerde geri dönüşümün sürdürülebilir modanın yaygınlaşmasına katk1 sağlayacağ 1 ve çevreye karşı olan duyarlılığ artıracağ 1 da katılımcılar tarafından belirtilmiştir. Gömlekleri yeniden değerlendirmeyi maddi durumu düşük olanların yapması gerektiğini düşünüyorum seçeneğinin \%57,5 (202) ile "3" derecesinde ve \%13,7 (48) ile "4" derecesinde tercih edilmiş olması oldukça dikkat çekicidir. Aynı şekilde "hazır giyim ürünleri ucuz olduğu için gömleklerin yeniden değerlendirilmesine ihtiyaç olmadığını düşünüyorum" seçeneğinin \%57,5 (202) ile " 3 " derecesinde ve \%16 (56) ile "4" derecesinde ve "zamanım olmadığı için giysilerin yeniden kullanımına yönelik faaliyetler yapamam" seçeneğinin \%37,3 (131) ile "4" derecesinde tercih edilmiş olması üzerinde durulması gereken noktalardandır. "Geri dönüşüm yöntemleri ile kullanılır hale getirilmiş gömlekleri giyerim" seçeneğinin \%46,2 (162) ile "4" derecesinde ve \%21,7 (76) ile "kesinlikle katılıyorum" derecesinde tercih edilmiş olması geri dönüşüm ve yeniden kullanım konusunda önemli kabul edilebilecek olumlu bir sonuçtur. Çağman (2010: 55)'ın araştırmasında çalışan kadınların \%98,8' inin giysilerini hazır aldıkları, \%0,6'sının kendisinin diktiği, \%0,4'ünün sipariş diktirdiği ve $\% 0,2$ 'sinin başkalarından aldığ 1 giysileri düzelterek giydikleri tespit edilmiştir. Her iki çalışma karşılaştırıldığında katılımcıların, geri dönüşüm ve yeniden kullanım konusunu önemli görmelerine rağmen zamanlarının kısıtlı olması, dikiş bilgilerinin olmaması ve hazır giyim ürünlerinin ucuz olması gibi sebeplerle geri dönüşüm için gerekli faaliyetleri kendilerinin yapmak istemedikleri/ yapamadıkları/ yapmadıkları ancak geri dönüşümü sağlanmış bir ürünü satın alıp kullanabilecekleri sonuçlarına ulaşılmıştır.

Tablo 6. Öğretmenlerin gömleklerin yeniden değerlendirilmesi konusundaki görüşleri

\begin{tabular}{|c|c|c|c|c|c|c|c|c|c|c|}
\hline \multirow{2}{*}{ SEÇENEKLER } & \multicolumn{2}{|c|}{$\begin{array}{c}\text { Kesinlikle } \\
\text { Katılmıyorum }\end{array}$} & \multicolumn{2}{|c|}{2} & \multicolumn{2}{|c|}{3} & \multicolumn{2}{|c|}{4} & \multicolumn{2}{|c|}{$\begin{array}{l}\text { Kesinlikle } \\
\text { Katıliyorum }\end{array}$} \\
\hline & $\mathrm{s}$ & $\%$ & $\mathrm{~s}$ & $\%$ & $S$ & $\%$ & $\mathrm{~s}$ & $\%$ & $\mathrm{~s}$ & $\%$ \\
\hline $\begin{array}{l}\text { Kullanılmayan gömleklerin/ yakaları, } \\
\text { manşetleri değiştirilerek yeniden } \\
\text { kullanılabilir }\end{array}$ & 2 & 0.6 & 10 & 2.8 & 274 & 78.1 & 43 & 12.3 & 22 & 6.3 \\
\hline $\begin{array}{l}\text { Kullanılmayan gömleklerin kumaşları } \\
\text { kullanılabilir }\end{array}$ & 13 & 3.7 & 35 & 10 & 137 & 39 & 109 & 31.1 & 57 & 16.2 \\
\hline $\begin{array}{l}\text { Kullanılmayan gömleklere farklı model } \\
\text { özelikleri kazandırılarak yeni giysiler elde } \\
\text { edilebilir (etek, elbise, çocuk giysisi, } \\
\text { aksesuar) }\end{array}$ & 15 & 4.3 & 67 & 19.1 & 64 & 18.2 & 159 & 45.3 & 46 & 13.1 \\
\hline $\begin{array}{l}\text { Kullanılmayan gömleklerin problemli } \\
\text { yerleri terziye tamir ettirilebilir }\end{array}$ & 15 & 4.3 & 43 & 12.3 & 97 & 27.6 & 117 & 33.3 & 79 & 22.5 \\
\hline $\begin{array}{l}\text { Kullanılmayan gömlekler ilgili kurum ya da } \\
\text { kişilere bağışlanabilir }\end{array}$ & 1 & 0.3 & 8 & 2.3 & 184 & 52.4 & 85 & 24.2 & 73 & 20.8 \\
\hline $\begin{array}{l}\text { Bu konu hakkında fikir sahibi değilim ve } \\
\text { geri dönüşüm konusu ilgimi çekmez }\end{array}$ & 56 & 16 & 38 & 10.8 & 184 & 52.4 & 58 & 16.5 & 15 & 4.3 \\
\hline
\end{tabular}


Tablo 6'ya göre; öğretmenlerin gömleklerin yeniden değerlendirilmesi konusundaki görüşleri incelendiğinde; \%78.1 (274) ile "kullanılmayan gömleklerin yakaları/ manşetleri değiştirilerek yeniden kullanılabilir", \%52.4 (184) ile "kullanılmayan gömlekler ilgili kurum ya da kişilere bağışlanabilir", \%52.4 (184) ile "bu konu hakkında fikir sahibi değilim ve geri dönüşüm konusu ilgimi çekmez", \%39 (137) ile "kullanılmayan gömleklerin kumaşları kullanılabilir" seçeneklerine " 3 " derecesinde katıldıkları belirlenmiştir. Öğretmenlerin \% 45,3 (159) ile "kullanılmayan gömleklere farklı model özelikleri kazandırılarak yeni giysiler elde edilebilir (etek, elbise, çocuk giysisi, aksesuar vb.)", \%33,3 (117) ile "kullanılmayan gömleklerin problemli yerleri terziye tamir ettirilebilir" seçeneklerini " 4 " derecesinde ifade ettikleri görülmüştür.

Katılımcılar, gömleklerin yaka ve manşetlerinin değiştirilerek yeniden kullanılabilir hale getirilmesi, kumaşlarının yeniden kullanılması, problemli yerlerinin terziye tamir ettirilmesi, ihtiyaç sahiplerine bağışlar yapılarak gömleklerin yeniden değerlendirilmesi şeklindeki öneri ve yöntemleri oldukça yüksek oranlarda önemsedikleri ortaya çıkmıştır. Öğretmenlerin vermiş oldukları cevaplar dikkate alındığında, geri dönüşüm ve yeniden kullanım konusunda oldukça olumlu yaklaşımlar içerisinde oldukları görülmektedir. Geri dönüşüm ve yeniden kullanımın sağlanıp yaygınlaştırılabilmesi için tüketicilerin teşvik edilmesinin ve ilgili imkânların kendilerine sunulmasının yeterli olacağı düşünülmektedir.

\section{Sonuç ve Öneriler}

Konya'da Millı̂ Eğitim Bakanlığı'na bağlı okullarda görev yapan öğretmenlerin gömlek satın alma davranışlarının ve gömleklere yönelik geri dönüşüm konusundaki görüşlerinin belirlenmesi amacıyla planlanıp yürütülmüş olan araştırmaya göre; 351 katılımcının 120'si kadın ve 231'i erkektir. Yaş dağılımları açısından incelendiğinde katılımcılar en fazla kırk-elli ve otuz bir-kırk yaş aralığındadır. Çalışmada satın alma sıklığı ölçülen ürün erkek tüketicilerin daha fazla kullanmakta olduğu bir giysi türü olan gömlektir. Bu nedenle araştırma sonuçlarında gömlek satın alma aralıklarının erkeklerde daha sık olduğu görülmüştür. Erkek tüketicilerin satın alma sıklıklarında "ayda bir ve üç ayda bir" seçeneklerinin kadın tüketicilere oranla daha fazla tercih edildiği görülmüştür.

Öğretmenlerin gömlek alışverişi yapma sıklıkları incelendiğinde; herhangi bir cinsiyetin daha fazla kullandığı bir giysi türüne sabitlenmeden yapılmış olan giysi satın alma alışkanlıklarına ilişkin araştırmalarda, kadın tüketicilerin giysi alışverişi yapma sıklıklarının daha dar aralıklarda olduğu görülmektedir. Örnek olarak, Budak (2012) tarafindan yapılmış olan araştırmada genel giyim alışverişi yapma sıklıklarına bakıldığında "kadın tüketicilerin" daha sık giysi alışverişi yaptıkları belirlenmiştir (Budak, 2012, s. 115). Öğretmenler tarafından gömlek alışverişi için aylık yapılan harcama miktarının "101-200 TL" aralığında olduğu bulunmuştur.

Öğretmenlerin en çok "klasik ve spor gömlekleri” en az ise "etnik gömlekleri” tercih ettikleri belirlenmiştir. Koca ve Koç' un çalışan kadınlar üzerine yapmış oldukları araştırmada da benzer şekilde, çalışan kadınların çoğunluğunun "klasik ve spor giyimi" tercih ettikleri görülmüştür (Koca ve Koç, 2008, s. 182). Bu bağlamda, ilgili araştırmalar incelendiğinde sonuçların birbirine paralel olduğu ve kamu da çalışanların genel olarak "klasik ve spor" giyim ürünlerini tercih ettikleri söylenebilir. Bu durumun sebebi; cinsiyet fark1 olmaksızın kamu sektöründe çalışan kesimin klasik giyinme zorunluluğu hissetmesi ve bu klasikliğin vermiş olduğu sıkıntı ile iş dışı yaşamda spor olma ihtiyacı olarak düşünülebilir.

Araştırma kapsamındaki öğretmenlerin gömlek alışverişi yapma sebepleri incelendiğinde genel olarak "eskimesi ve beden ölçülerinde değişiklik olması" durumlarında alışveriş yaptıkları görülmüştür. Dolayısıyla katılımcıların büyük çoğunluğunun gerekli olduğu durumlarda, ihtiyaç halinde gömlek alışverişi yaptıkları söylenebilir. Çağman (2010)'ın çalışan kadınlar üzerine yaptığ çalışmada, kadınların büyük çoğunluğunun gerekli olduğu zaman giysi satın aldığı sonucuna ulaşılmıştır (Çağman, 2010, s. 55). Budak (2012)'ın tüketicilerin giysi satın alma davranışları üzerine yaptığı araştırmada da katılımcıların yarısından fazlası giyim 
ürünlerini satın almalarında "ihtiyaç olma durumunun" birinci derecede etkili olduğunu ifade etmişlerdir (Budak, 2012, s. 126).

Tüketicilerin alışveriş tercihlerini yönlendiren birçok faktör bulunmaktadır. Satın alma davranışı üzerinde diğer insanların etkisi sosyal faktörler olarak ifade edilmektedir. Sosyal faktörler üç grupta toplanabilir: aile, referans grupları, roller ve statüler. Durmaz ve Bahar tarafından tüketicilerin satın alma davranışları üzerine yapılmış olan araştırmada da katılımcıların büyük çoğunluğunun ailenin beğenmesinin en önemli faktörlerden biri olduğunu belirttikleri görülmektedir (Durmaz ve Oruç, 2011, s. 60-77).

Öğretmenler gömlek alışverişinde en çok modeli, yaşa uygunluğu, kalitesi ve kumaşı faktörlerini tercih etmişlerdir. En az ise modaya uygunluk seçeneğini önemli bulmuşlardır. Çağman (2010)' in çalışan kadınlar üzerine yapmış olduğu çalışmada giysi satın alan çalışan kadınların yarısından fazlasının modayı takip etmediği görülmektedir (Çağman, 2010, s. 55). Aktuğlu ve Temel' in, "kamu sektörü çalışanlarının giysi markalarını tercihini etkileyen faktörlere yönelik bir araştırma" adlı çalı̧̧malarında tüketicilerin giysi satın alma tercihlerini etkileyen faktörler incelendiğinde: "rengi/modeli/stili" ve "kalitesi" faktörleri büyük oranda "her zaman etkili olur" şeklinde tercih edilmiştir (Aktuğlu ve Temel, 2006, s. 53). Araştırma sonuçları birbirlerini destekler niteliktedir.

Öğretmenler gömlek modellerinde en çok yaka, manşet, çizgili kareli olması, kırışmazlık, kolay ütülenebilir olması, terletmemesi, kumaşın pamuklu olması özelliklerini tercih etmişlerdir. En az ise "arma, logo veya markasının görünür olması, markanın sezon sonu veya geçmiş sezon ürünü olması, pahalı bir markaya ait olması, bilindik bir markaya ait olması" özelliklerini tercih etmişlerdir.

Öğretmenlerin gömlek satın alırken karşılaştıkları problemler incelendiğinde; en çok beden ölçülerine uygun ve farklı modellerde gömlek bulamadıkları belirlenmiştir.

Öğretmenlerde gömlek kullanımında ise en çok "yakalarının çabuk aşınması, kumaşların yıpranması ve manşetlerin yıpranması" sorunları ile karşılaşıldığı görülmüştür. Öğretmenlerin en çok gömlek üretiminde kullanılan hammadde olan kumaştaki yıpranma sebebiyle problem yaşadıkları söylenebilir.

Öğretmenlerin kullanılmış giysileri değerlendiren herhangi bir organizasyon, kurum veya projeden haberdar olma durumları incelendiğinde; katılımcıların büyük çoğunluğunun kullanılmış giysileri değerlendiren herhangi bir organizasyon, kurum veya projeden haberdar olmadıkları görülmektedir.

Öğretmenler, gömleklerin yeniden kullanılabilir hale getirilmesinin aile ve ülke ekonomisine olumlu katkılar sağlayacağını, yeni istihdam alanları oluşturacağını ve gömleklerin yeniden değerlendirilmesine yönelik projeler geliştirilmesinin önemli olduğunu belirtmişlerdir. Bunların yanında gömleklerde geri dönüşümün sürdürülebilir modanın yaygınlaşmasına katkı sağlayacağı ve çevreye karşı olan duyarlılığı artıracağı da katılımcılar tarafından belirtilmiştir.

Öğretmenler, gömleklerin yaka ve manşetlerinin değiştirilerek yeniden kullanılabilir hale getirilmesi, kumaşlarının yeniden kullanılması, problemli yerlerinin terziye tamir ettirilmesi, ihtiyaç sahiplerine bağışlar yapılarak gömleklerin yeniden değerlendirilmesi şeklindeki öneri ve yöntemlere yüksek oranlarda katılmışlardır.

Araştırmaya göre; katılımcıların geri dönüşüm ve yeniden kullanım konusunda oldukça olumlu yaklaşımlar içerisinde oldukları görülmektedir. Geri dönüşüm ve yeniden kullanımın yaygınlaştırılabilmesi için tüketicilerin teşvik edilmesinin ve ilgili imkânların kendilerine sunulmasının gerekli olduğu düşünülmektedir.

Katılımcıların atık haline geldiğini düşündükleri giysilerini, gömleklerini bazı basit biçki, dikiş teknikleri uygulayarak "yeniden kullanıma" devam edebilecekleri söylenebilir. Katılımcıların, geri dönüşüm ve yeniden kullanım konusunu önemli görmelerine rağmen, 
mevcut şartlarda zamanlarının kısıtlı olması, dikiş bilgilerinin olmaması ve hazır giyim ürünlerinin ucuz olması gibi sebeplerle geri dönüşüm için gerekli faaliyetleri kendilerinin yapacaklarını söylemek gerçekçi olmaz. Yıpranma, eskime, beden ölçülerinde değiş̧iklik veya modasının geçmesi ile ömrü tamamlandığı düşünülen bir giysinin basit biçki- dikiş teknikleri ile yeniden kullanıma alınabilmesi mümkünken modern zamanın getirmiş olduğu meşguliyet, alışkanlık ve kabuller sebebiyle, insanlar "geri dönüşüm veya yeniden kullanım" faaliyetine mesafeli yaklaşıyor olabilirler.

Katılımcıların, geri dönüşüm ve yeniden kullanım konusunu önemli görmelerine rağmen zamanlarının kısıtlı olması, dikiş bilgilerinin olmaması ve hazır giyim ürünlerinin ucuz olması gibi sebeplerle geri dönüşüm için gerekli faaliyetleri kendilerinin yapmak istemedikleri/ yapamadıkları/ yapmadıkları ancak geri dönüşümü sağlanmış bir ürünü satın alıp kullanabilecekleri sonuçlarına ulaşılmıştır.

Tüketim sonrasında oluşan tekstil ve hazır giyim atıklarının geri dönüşüm, yeniden kullanım ve geri kazanımıyla ilgili olarak bazı öneriler sunulabilir:

- Bu atıkların, atık kutuları veya evlerden atıkların alınması yöntemleri ile toplanarak sinıflandırılmaları ve kullanılabilecek durumda olanların ikinci el giysi olarak değerlendirilmeleri, kullanılamayacak durumda olanların ise geri kazanım işletmelerine gönderilmeleri,

- Giysi toplama merkezlerinin yeniden kullanım açısından büyük önem taşıdığı ve atık hale gelmiş giysilerin toplama, tasnif, tamir ve temizleme işlemlerinden giysi toplama merkezlerinde ihtiyaç sahiplerine ulaştırılabileceği,

- Takas usulü yöntemi ile giysilerin yeniden kullanıma sunulabileceği,

- Giyim eşyalarını "yeniden kullanılabilir" hale getirebilecek donanım ve anlayışta insanlar ancak eğitim- öğretim faaliyetleriyle yetiştirilebilir. İlköğretimden itibaren eğitim- öğretim müfredatımızda sürdürülebilirlik, ekoloji, geri dönüşüm ve bu bağlamda biçki- dikiş uygulamalarının yer alması,

- Diğer taraftan, atık haline gelmiş giysi veya gömleklerin bir terzi yardımıyla yeniden kullanıma kazandırılmaları gerektiği; giysilerin atık kutuları veya benzeri yöntemlerle belediyeler ve sosyal yardım kuruluşları vasıtasıyla toplanarak ihtiyaç sahiplerine ya da geri dönüşüm işletmelerine ulaştırılmaları gerektiği, öneri olarak sunulabilir.

\section{Kaynakça}

Aktuğlu, I. K., ve Temel, A. (2006). Kamu sektörü çalışanlarının giysi markalarını tercihini etkileyen faktörlere yönelik bir araştırma. Selçuk Üniversitesi Sosyal Bilimler Enstitüsü Dergisi, 15, 43- 59.

Batalier, M. (t.y.). The textile 1ssue - london textile forum 2018: What, why, how and when? London Sustainability Exchange. http://www.lsx.org.uk/blog/textile-issue-london-textileforum-2018/ (Erişim tarihi: 11.08.2020).

Budak, E. (2012). Hazır giyim sektöründe tüketicilerin satın alma davranışlarını etkileyen psikolojik faktörlerin bütünleşik analizi (Yüksek lisans tezi). Ege Üniversitesi, İzmir.

Çağman, D. S. (2010). Çalışan kadınların giysi kullanım süreleri ve kullanım sonrası giysileri değerlendirme yöntemleri (Yüksek lisans tezi). Gazi Üniversitesi, Ankara.

Durmaz, Y., ve Bahar, R. (2011). Tüketicilerin satın alma davranışları üzerinde sosyolojik faktörlerin etkisinin incelenmesine yönelik bir çalışma. Elektronik Sosyal Bilimler Dergisi, 10 (37), 60-77. 
Global Fashion Agenda \& The Boston Consulting Group. (2017). Pulse of the fashion industry, 8. https://www.globalfashionagenda.com/publications-and-policy/pulse-of-the-industry/ (Erişim tarihi: 13.07.2020).

İstanbul Tekstil ve Konfeksiyon İhracatçı Birlikleri. (2005). Tekstil konfeksiyon sektöründe ekoloji ve ekolojik etiketler, ITTKIB AR\&GE ve Mevzuat Şubesi. https:// www. yumpu. com/tr/ document/read/23582613/ tekstilde-ekoloji-uenco (Erişim tarihi: 11.05.2019).

İstanbul Tekstil ve Konfeksiyon İhracatçı Birlikleri. (2021). Sürdürülebilirlik. Hedef Dergisi, 326.

Joy, A., Sherry, J. F., Venkatesh, A., Wang, J., \& Chan, R. (2012). Fast fashion, sustainability, and the ethical appeal of luxury brands, Fashion theory. 16(3), 274. Erişim adresi: https:// www3. nd. edu/ jsherry/pdf/2012/FastFashionSustainability.pdf

Jung, S., \& Jin, B. (2014). A theoretical investigation of slow fashion: sustainable future of the apparel industry, International Journal Of Consumer Studies, 38, 510-519.

Koca, E., ve Koç E. (2008). Çalışan kadınların giysi seçimleri ve renk tercihleri. Elektronik Sosyal Bilimler Dergisi, 7 (24), 171-200.

Ninimaki, K., \& Hassi, L. (2011). Emerging design strategies in sustainable production and consumption of textiles and clothing. Journal of Cleaner Production, 19, 1876-1883, Journal Homepage: www.elsevier.com/locate/jclepro.

Özüdoğru, Ş. (2013). 19. Yy.dan günümüze moda ve sanat etkileşimi (Yüksek lisans tezi). Anadolu Üniversitesi, Eskişehir.

Shen, D., Richards, J., \& Liu, F. (2013). Consumers awareness of sustainable fashion. The Marketing Management Journal, 23(2), 134-147.

Sönmez, V., ve Alacapınar, F.G. (2011) Örneklendirilmiş bilimsel araştırma yöntemleri. Ankara: Anı Yayınları.

Şahin, A. (2009). Giysi alışverişinde tüketicilerin haute couture ve hazır giyim tercihleri İstanbul- Konya illerinde örnek bir araştırma (Yüksek lisans tezi). Selçuk Üniversitesi, Konya.

Üçgül, İ., ve Elibüyük, U. (2014). Tekstil atıklarının piroliz ile değerlendirilmesi. SDÜ Teknik Bilimler Dergisi, 4(2), 40-46.

\section{ETIKK ve BİLIMSEL İLKELER SORUMLULUK BEYANI}

$\mathrm{Bu}$ çalışmanın tüm hazırlanma süreçlerinde etik kurallara ve bilimsel atıf gösterme ilkelerine riayet edildiğini yazar(lar) beyan eder. Aksi bir durumun tespiti halinde Afyon Kocatepe Üniversitesi Sosyal Bilimler Dergisi'nin hiçbir sorumluluğu olmayıp, tüm sorumluluk makale yazarlarına aittir.

\section{ARAȘTIRMACILARIN MAKALEYE KATKI ORANI BEYANI}

1. yazar katkı oranı : $\% 60$

2. yazar katk1 oran $1 \% 40$ 